EGU2020-13217

https://doi.org/10.5194/egusphere-egu2020-13217

EGU General Assembly 2020

(c) Author(s) 2020. This work is distributed under

the Creative Commons Attribution 4.0 License.

\title{
Study of nitrogen compounds in different atmospheric compartments
}

Christelle Ghaffar, Maxence Brissy, Binta Dieme, Martin Lerembourg, Marcello Brigante, and Pierre Amato

Université Clermont Auvergne, CNRS, Institut de Chimie de Clermont Ferrand, France

Nitrogen molecules are present in the atmosphere also as inorganic ions (ammonium, nitrate...) and organic (peptides and proteins). Nowadays, there is still poor knowledge concerning the sources and fate of proteins and peptides in the atmosphere. In a larger context aiming at exploring microbial communities' functioning in the atmosphere, the goal of this study is to examine the atmospheric proteome (peptide and protein contents, sequence, size distribution, biological functions) in the different atmospheric compartment (aerosols, cloud and rain waters).

Aerosols, cloud water and rain samples were collected at remote places nearby Clermont Ferrand city (France) and from the Mountain "Puy de Dôme" (1465 m asl). Cloud droplet impactors and high volume impingers were used for allowing immediate fixation of the samples, by collecting within a protease inhibitor solution. Samples were filtered $(0.22 \mu \mathrm{m}$ porosity) and the proteins from water were digested using trypsin. The peptides were purified by solid phase extraction (SPE) method, concentrated by lyophilisation and analysed by LC - HRMS and MS2. Preliminary results indicate the recurrence of certain small peptides in particular. Some of these most frequently observed peptides were selected as models for photochemical experiments. Briefly, these small peptides were irradiated under solar simulated conditions and products were identified by IC - MS, to assess the impact of such processes on the chemical composition of the atmosphere.

The next step will consist in analysing our observations along with chemical and biological parameters such as biodiversity, transcriptomic profiles, in order to better understand the interaction between microorganisms and atmosphere processes. 